\title{
Correction: Study of the measurement and predictive validity of the Functional Movement Screen
}

Philp F, Blana D, Chadwick EK, et al. Study of the measurement and predictive validity of the Functional Movement Screen. BMJ Open Sport Exerc Med 2018;4:e00357.

During the proofing process the correct numbering was removed from table 1 . We now publish the correct formatting for table 1 .

\begin{tabular}{|c|c|}
\hline \multicolumn{2}{|l|}{ Deep Squat } \\
\hline FMS rules & Number of variables for consideration in real time by the assessor \\
\hline $\begin{array}{l}\text { Upper torso is parallel } \\
\text { with tibia or towards } \\
\text { vertical }\end{array}$ & $\begin{array}{l}\text { 1. Thorax inclination angle must be less than the tibial } \\
\text { inclination angle }\end{array}$ \\
\hline Femur below horizontal & $\begin{array}{l}\text { 2. Long axis of the left femur must pass through the horizontal } \\
\text { 3. Long axis of the right femur must pass through the horizontal }\end{array}$ \\
\hline Knees aligned over feet & $\begin{array}{l}\text { 4. Left knee joint centre does not exceed medial and lateral } \\
\text { borders of the foot in the coronal plane } \\
5 \text {. Right knee joint centre does not exceed medial and lateral } \\
\text { borders of the foot in the coronal plane }\end{array}$ \\
\hline
\end{tabular}

6. Left dowel position (forwards) does not exceed anterior foot border in the sagittal plane

7. Left dowel position (backwards) does not exceed heel position in the sagittal plane

8. Right dowel position (forwards) does not exceed anterior foot border in the sagittal plane

9. Right dowel position (backwards) does not exceed heel

Dowel aligned over feet position in the sagittal plane

Keeping your heels in position
10. Left heel displacement must not exceed $5 \mathrm{~mm}$ vertically

11. Right heel displacement must not exceed $5 \mathrm{~mm}$ vertically

Open Access This is an Open Access article distributed in accordance with the Creative Commons Attribution Non Commercial (CC BY-NC 4.0) license, which permits others to distribute, remix, adapt, build upon this work non-commercially, and license their derivative works on different terms, provided the original work is properly cited and the use is non-commercial. See: http://creativecommons.org/licenses/by-nc/4.0/

(C) Article author(s) (or their employer(s) unless otherwise stated in the text of the article) 2018. All rights reserved. No commercial use is permitted unless otherwise expressly granted.

BMJ Open Sport Exerc Med 2018;4:e00357corr1. doi:10.1136/bmjsem-2018-000357corr1

Check for updates 